\title{
A NOTE ON ADMINISTRATIVE ADJUDICATION
}

\author{
PHILIP ELMAN $\dagger$
}

THE distinctive characteristic of the administrative process is its blending of different functions and powers in a single agency. The basic duty of an administrative agency is to implement, using the wide variety of tools given it by Congress, the regulatory policies established by statute. For example, the Federal Trade Commission has as its primary task the prevention of the use in interstate commerce of unfair, deceptive, and anticompetitive business practices. The Commission has been empowered to perform this task in various ways: it can investigate; it can prosecute; it can adjudicate; it can guide and advise; it can conduct and publish economic studies; it can issue rules and statements of policy.

This fusion of functions has raised questions as to the integrity, as well as the effectiveness, of the administrative process. I should like briefly to explore, with particular reference to the Federal Trade Commission, the agency I know best, one of those questions: Can an administrative agency, which would appear to be so different an institution from a court, be depended upon to discharge the function of adjudication fairly and impartially?

Although administrative adjudication is a term sometimes used loosely, the Federal Trade Commission has at least one function which is indisputably judicial in character. If the Commission has reason to believe that a person is violating any of the laws it administers, and if it appears that a proceeding would be in the public interest, the Commission issues a formal complaint. The proceeding that follows before a hearing examiner is, with minor variations, similar to a court action governed by the Federal Rules of Civil Procedure. If the Commission, on review of the examiner's decision, finds that the alleged violations of law have been proved, it can (subject to judicial review of its decision) apply sanctions similar to those of a court of equity.

As in a judicial proceeding, the agency's decision must be based on the record, findings must be supported by the evidence, and the burden of proof rests upon the charging party. The basic differences between judicial and administrative adjudication are not differences of procedure; they are differences in the institutional environment in which adjudication takes place. For while adjudication is the sum and substance of the judicial process, it is only a part, and not always the largest or most important part, of the administrative process.

The judicial process is designed to insure that the judge is both neutral and disinterested. The ideal judge is a detached, even aloof, arbiter of controversies in whose outcome he has no interest other than that of applying the law fairly and evenhandedly. Strictly insulated from the initiation and prosecution of cases, a judge ordinarily has but limited control over his own docket. Moreover, assuming his jurisdiction is general, a judge rarely acquires an expert's

tCommissioner, Federal Trade Commission. 
knowledge of the matters coming before him, further assuring that he vill approach each new case with an open mind.

By contrast, agency members have a more active and affirmative commitment to achieving the goals and effectuating the policies declared by Congress; their success is measured by the agency's results in striving to attain those positive objectives. Agency members, furthermore, are expected to be experts, bringing to each case a specialized knowledge informed by experience. Such knowledge and experience is not, and should not be, confined to the record of a particular case.

Even if we go no further, it should be apparent that the requirements of the administrative process, which do not allow for the shielding of agency members, as judges are shielded, from responsibility for producing successful results in advancing the policies announced by Congress, complicate the task of adjudicating particular cases. But there are other stresses and strains on agency adjudication that must be noted. Apart from improper external pressures, conflicts of interests, ex parte communications, and the like, there remain those subtle institutional influences which no laws, regulations, or codes of ethics can remove, and which will best be overcome if they are forthrightly recognized.

It is by no means unusual for an agency to decide that a complaint which it issued should be dismissed because the evidence or the legal theory on which it was based did not stand up under adversary attack. For example, of the appeals decided by the Federal Trade Commission in the past year, about onethird resulted in dismissals of the complaint. Still, it is likely that decisions of this kind are generally less reluctantly made by judges than by the members of an agency. Not having issued the complaint, the judge need not concern himself with whether a dismissal will be construed as an admission of error in issuing the complaint and of a waste of the public's and the respondent's time and money in fruitless proceedings. Nor need he have any apprehension that dismissal of the case will impair staff morale. And a judge is not subjected to the mischievous suggestion that a case ought not be dismissed because judicial review is thereby precluded, or the equally mischievous notion that the success of an agency is measured by the number of cease and desist orders it enters.

Considerations of this sort illustrate the inherent perils to fair and impartial agency adjudication. Yet there are within the existing framework of the administrative process a number of steps that can and should be taken to assure a greater fairness and impartiality.

First of all, case-by-case adjudication as a technique of administrative law enforcement should be substantially de-emphasized. As I have discussed more fully elsewhere, ${ }^{1}$ litigation is an intolerably slow, costly, clumsy, fragmentary,

1. Elman, The Federal Trade Commission and the Administrative Process, 8 AxrsTRUST BULL. 607 (1963); Elman, The Impact of Antitrust on Economic Growth: The National Issue, in Transcript of THIRd Conference on ANtrtrust in an Expasidiza Economy, Marci 5, 1964, at 36-47 (1964); Elman, Rulemaking Procedures in the FTC's Enforcement of the Merger Law, 78 HARV. L. REv. 385 (1964). 
and inadequate process for resolving the delicate and complex economic issues that characterize the field of trade regulation. The FTC should make more use of the other regulatory tools available to it; in the past three years, it has been doing so with increasing frequency. To the degree that an agency utilizes nonadjudicatory techniques, it avoids the inherent problem of adjudicative fuirness. However, some questions yield only to the case-by-case method of inclusion and exclusion; and adjudication is, after all, the method of policy for* mulation which many agencies, including the Federal Trade Commission, know best.

It should be emphasized that it is this function of policy formulation which is the essential and non-delegable duty of an agency member. Therefore, he is aided, not hindered, by relief from responsibility for weighing specific evidence against designated persons in particular cases. In relieving the overburdened agency member, internal delegations, both at the complaint-isstance and appeal-deciding stages, can also do much to assure greater fairness in adjudication. As I have proposed before, ${ }^{2}$ the Commission should make more use of a limited delegation of authority with respect to the issuance of complaints. Specifically, the members of the Commission should not, at the complaintissuance stage, undertake to make their own assessments of the evidence regarding violation of law. They should limit their inquiry at that stage to considerations of law and public interest, leaving to a high-level staff official or group acting under Commission policy directives the determination of whether there is sufficient evidence of violation in a particular case to warrant prosecution. A Commissioner who spends much of his time reviewing investigative files at the pre-complaint stage may be disabling himself from discharging those policy-making and adjudicative responsibilities which are his alone and cannot be delegated to others. But, more important, a Commission member who does not review the investigative files at the complaint-issuance stage is not open to the charge of acting as prosecutor and judge in the same case. Rather, he functions like a judge who, in overruling a demurrer, finds only that the complaint states a cause of action - not that it has been proved or can probably be proved.

At the appeal-deciding stage, greater deference should be accorded to the findings made by hearing examiners on disputed issues of fact the resolution of which does not call for application of the accumulated experience and special knowledge of the agency. A hearing examiner should be regarded as the agency's special master on fact questions. The independence of hearing examiners, specifically their isolation from the complaint-issuance process, is a substantial safeguard against unfairness in administrative adjudication. We strengthen that safeguard, and at the same time help the agency members concentrate on their basic function of formulating law and policy, by attaching greater finality to examiners' findings on strictly factual questions. To the ex-

2. Elman, The Federal Trade Commission and the Administrative Process, supra noto 1 , at 613-14. 
tent that agency members limit their role as judges of the particular facts, they enlarge their primary role as administrators.

Agency members should concern themselves more with general problems and broad solutions, and less with individual cases and narrow adjudications. Agencies were especially created not to decide issues like "Did X Company do these particular acts charged against it?", but rather to consider questions such as "Is it unfair and anticompetitive for companies in this industry to engage in this kind of practice?" The more agency members immerse themselves in the former type of question, the less able they are to deal with the latter.

But greater delegation and other procedural reforms will by themselves accomplish little. Improvements in the fairness of agency adjudication will not come until agency members frankly acknowledge, and conscientiously seek to avoid, the dangers inherent in the fusion of functions within the administrattive process. A lapse from fairness in agency adjudication is more likely to derive from an unconscious yielding to institutional factors than from a cynical disregard for the duty to judge impartially. This danger could be mitigated if agency members were alert to it and determined to resist.

Finally, as has been said so often but not yet fully accepted, the highest standards of integrity, independence, character, and ability must be demanded in the appointment of members of federal administrative agencies. For, as Gerard Henderson observed in his classic study of the Federal Trade Commission," "Impartiality and fair-mindedness are personal qualities. There are men who can preserve a detached and judicial point of view, however much their relation to the controversy may draw them toward one side or another." Why not candidly acknowledge that to judge fairly in the framework of the administrative process may be more difficult and demanding than to judge fairly as a member of a judicial tribunal, and that therefore the standards of fitness for agency appointments should be at least as high as those governing the selection of federal judges?

The questions raised here are troublesome, and are not to be brushed aside. They troubled me when I joined the FTC in 1961, and they still trouble me. One answer - which I have rejected not because it:is too drastic but because it is not responsive to the real needs of the situation - is to relieve the agencies entirely of their adjudicative function. Such a proposal would create more problems than it solves and would leave the administrative process less rather than more effective. ${ }^{5}$ For if an "administrative court" confined itself narrowly to the resolution of purely evidentiary issues and assumed no responsibility for formulating legal standards and policies, it would only be performing a function better left to independent hearing examiners, as under the present

3. Henderson, The federai Trade Comanission (1924).

4. Id. at 327.

5. This point has recently been made in a cogent and persuasive article by a former Chairman of the SEC. See Cary, Why I Oppose the Divorce of the Judicial Fumetion From Federal Regulatory Agencies, 51 A.B.A.J. 33 (1965). 
system. But if, as is almost inevitable, such a court found it impossible to decide particular cases without confronting questions of substantive law and administrative policy, it would perforce become a competing organ of law and policy making. The resulting diffusion of responsibility would impede, not advance, progress towards the solution of the most serious problem of the administrative process : the failure of the agencies to translate general statutory principles into specific, clearly articulated standards and policies.

If one believes, as I do, that the administrative process is an indispensable tool of democratic government and that the structure of the federal administrative agencies is basically sound and is likely to remain substantially un. changed in the foreseeable future, he is under greater obligation to look squarely at the perils that seem to inhere in agency adjudication. Facing realities is usually a good way to begin dealing with them. 


\section{THE YALE LAW JOURNAL}

\begin{tabular}{lll}
\hline VOLUME 74 & MARCH 1965 & \\
\hline
\end{tabular}

\begin{abstract}
JoHN GrIfFItHS
OWen J. SLOANR

Altan A. Tutrle

MichaEl A. VARET

Note \& Comment

Editors
\end{abstract}

\section{Charles M. Nathax Editor-in-Chief}

\begin{tabular}{|c|c|}
\hline $\begin{array}{r}\mathrm{DA} \\
T \\
\mathrm{C} \\
\mathrm{SB} \\
\\
\end{array}$ & 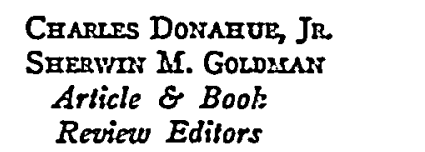 \\
\hline \multicolumn{2}{|l|}{$\begin{array}{l}\text { MarTIN E. LoWY } \\
\text { Mantaging Editor }\end{array}$} \\
\hline $\begin{array}{l}\text { JAMRES S. GORDON } \\
\text { MICHAEL F. HALLORAN } \\
\text { B. BOYD HIGET, JR. } \\
\text { C. STEPHEN HOWARD } \\
\text { GEORGE I. JUROW } \\
\text { HOWARD A. KNIGET } \\
\text { MARIN D. KRALL } \\
\text { SIMON LAZARUS, III } \\
\text { BETSY LEWIN } \\
\text { RONALD F. LIPP } \\
\text { CANIERON F. MACRAE, III } \\
\text { FREDERICK B. MICLANE } \\
\text { ROD MCAIAHAN } \\
\text { LEONARD M. MARIS }\end{array}$ & 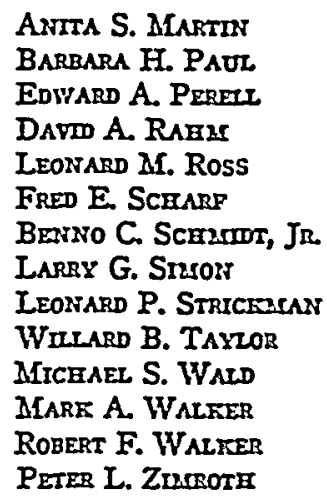 \\
\hline & $\begin{array}{l}\text { etcas Seronenanuzs } \\
\text { Business Secrelary }\end{array}$ \\
\hline
\end{tabular}

JOHN R. ADLER

JonathaN A. Ater

Richard J. Braesirer

DenNis $K$. Brostey

E. EDWARD BRUCE

Cenarles N. Burger

Robert A. CARTER

Rayarond C. Clevenger, III

Dennis E. Curtis

ANTHoNy A. Deas

WAIter E. DezLINGER, III

W. LeE H. Dungam

Roger D. FeIDASAN

Gregory C. GiynN

JANIES T. B. TrIPP

Business Manager

\section{CONTRIBUTORS TO THIS ISSUE}

EugENe V. Rostow. B.A. 1933, LL.B. 1937, A.M. 1944, Yale University.

Thomas I. Emerson. B.A. 1928, LL.B. 1931, M.A. 1946, Yale University.

Fleartng JANIES, JR. B.A. 1925, LL.B. 1928, Yale University.

WIILIA3r W. VAN ALstyne. B.A. 1955, University of Southern Californiz; LL.B. 1958, Stanford University.

Ronald Dworknn. B.A. 1953, LL.B. 1957, Harvard University; B.A. 1955, Oxsord University.

Phimr Elaran. A.B. 1936, College of the City of New York; LL.B. 1939, Harvard University.

WILliaM F. SwINDLER. A.B. \& B.S. 1935, Washington University; M.A. 1936, Ph.D. 1942, University of Missouri; LL.B. 1958, University of Nebraska.

Gary Fronar. B.M.E. 1956, Cornell University; MI.S. 1958, Mrassachusetts Institute of Technology; A.M. 1959, Ph.D. 1960, Harvard University.

Hugo J. HAHn. LL.MY. 1952, Harvard University; Dr. Jur. 1953, University of Frankfurt 